\title{
ANALISIS RESPON DAN FAKTOR-FAKTOR YANG MEMPENGARUHI PETANI TERHADAP PENERAPAN PERTANIAN ORGANIK DI KOTA MATARAM
}

\author{
Aeko Fria Utama $\mathrm{FR}^{\mathbf{1}^{*}}$, Muhammad Nursan ${ }^{1)}$ \\ ${ }^{1}$ Universitas Mataram, Indonesia \\ ${ }^{*}$ Corresponding author : aekomarya40@gmail.com
}

To cite this article:

Utama FR, A., \& Nursan, M. (2020). Analisis Respon dan Faktor-Faktor yang Mempengaruhi Petani terhadap Penerapan Pertanian Organik di Kota Mataram. JIA (Jurnal IImiah Agribisnis) : Jurnal Agribisnis dan IImu Sosial Ekonomi Pertanian, 5(3), 93 - 103. doi:http://dx.doi.org/10.37149/jia.v5i3.12140

Received: May 16, 2020; Accepted: June 22, 2020; Published: June 30, 2020

\begin{abstract}
The city of Mataram is the potential region for developing organic agriculture and has prepared a policy of using organic materials for farmers in conducting their farming. One of the policies of the Mataram City Government in supporting organic farming practices is to provide assistance production equipment like organic fertilizer counters for each farmer group for each farmer group. But in reality, at this time there are still not many farmers who want to do an organic farming system in their farming business. The aimsof this study are to 1) Determine farmers' responses to organic agriculture, and 2) link the factors that encourage farmers to apply organic farming.. This research was conducted in two districts namely Selaparang Subdistrict and Sekarbela Subdistrict, Mataram City, which were selected by purposive sampling. The data in this study is cross section data obtained from interviews with 40 people taken by quota sampling. The data collected was analyzed using a categorical data analysis model. Farmers' responses Analysis to organic farming are used 4 indicators namely knowledge, perception, attitude and practice or application. The results show that the response of organic farmers to organic farming depended on positive results, because according to respondents organic farming is beneficial for soil fertility were very high, could reduce environmental pollution and could increase increased agriculture. While the response of non-organic farmers is moderate / less positive range. This causes the complexity of the application of organic agriculture both in terms of fertilization and when spraying pests and diseases. Factors that support farmers in implementing organic farming systems in the city of Mataram are the role of extension workers, approval of agricultural technology and capital. While the factors that hamper farmers involving organic agriculture are farmer prices, prices of organic products which are the same as nonorganic products, capital, access to information and access to organic agricultural production
\end{abstract}

Keywords: farmers' responses; mataram city; obstacle factors; organic agriculture; supporting factors.

\section{PENDAHULUAN}

Sektor pertanian memiliki peran penting dalam perekonomian nasional karena mayoritas penduduk di Indonesia memiliki mata pencaharian utama sebagai petani. Kontribusi sektor pertanian mencapai $15 \%$ terhadap PDB dan sekitar 35,1\% angkatan kerja berada pada sektor pertanian (Wibowo, 2012).Sistem pertanian di Indonesia saat ini masih didominasi oleh sistem pertanian konvensional dengan penggunaan bahan kimia yang tinggi sehingga dapat membawa dampak buruk seperti menyebabkan degradasi lahan, kurangnya kesuburan dan kelembaban tanah, dapat merusak ekosistem, erosi, dan berdampak pada kesehatan para konsumen akibat penggunaan pestisida Kementerian Pertanian, 2016). Selain itu FAO (2013) mengemukakan bahwa pertanian konvensional juga membawa dampak terhadap perubahan iklim karena sebagai sektor penyumbang emisi. Sumber emisi pertanian dapat meliputi emisi langsung pertanian (agriculture's direct emission) dan emisi tidak langsung pertanian. Emisi langsung pertanian seperti penggunaan pupuk an-organik, lahan sawah yang tergenang, pembakaran biomas, dan aktivitas peternakan (respirasi enterik dan pengeloaan kotoran hewan) sedangkan emisi pertanian yang bersifat tidak langsung (agriculture's 
indirect emission) seperti penggunaan bahan bakar fosil, proses produksi agrokimia, dan perubahan penggunaan lahan.

Beberapa dekade yang lalu telah diluncurkan konsep revolusi hijau sebagai program nasional untuk peningkatan produksi pangan di Indonesia merupakan contoh praktik pertanian konvensional. Namun, konsep pertanian ini tidak berlangsung lama, karena mengakibatkan degradasi lahan pertanian secara terus menerus (Kementerian Pertanian, 2016). Oleh karena itu, tantangan pertanian di masa depan adalah bagaimana menghasilkan pertanian yang adaptif dengan perubahan iklim, memiliki produktivitas yang tinggi, dan mampu menekan jumlah emisi gas rumah kaca (Setyanto, et al, 2013). Diperlukan suatu sistem pertanian yang berkelanjutan untuk mengurangi dampak perubahan iklim yang diakibatkan oleh sistem pertanian konvensional. Hal ini dikarenakan sistem pertanian berkelanjutan memiliki produktifitas dan mampu menjaga sumber daya alam (Sudalmi, 2010). Selain itu, sistem pertanian ini mampu ,menghasilkan sistem pertanian yang adaptif dan mampu memitigasi perubahan dampak iklim (Beddington, et al. 2012).

Pertanian organik merupakan contoh praktik sistem pertanian berkelanjutan dengan penggunaan bahan organik alami. Dimana sistem pertanian organik berifat holistik yang mampu meningkatkan dan mengembangkan kelestarian agroekosistem, keragaman hayati, siklus dan aktivitas biologi tanah, serta bersifat adaptif dan berkontribusi dalam mitigasi emisi gas rumah kaca (FAO, 2011; Gattinger, et al. 2012).

Di Indonesia sistem pertanian organik sudah dimulai sekitar tahun 1990, dan bukan suatu teknik budidaya baru (Husnain, et al, 2015), bahkan sebelum era revolusi hijau dimulai sistem ini sudah dipraktekkan. Memasuki awal abad ke-21, isu pertanian organik mulai populer kembali di Indonesia. Gaya hidup "back to nature" muncul dan orang lebih sadar tentang dampak negatif dari input agro-kimia (Jahroh, 2010). Pertanian organik kembali menjadi daya tarik dengan adanya kesadaran masyarakat terhadap keamanan pangan dan kelestrarian lingkungan (Mayrowani, 2012)dan memilih produk yang aman dan sehat sehingga berpotensi merangsang peningkatan permintaan produk organik dan menunjukkan prospek bisnis organik ini sangat menjanjikan di masa depan (Shiotsu, et al, 2015).

Luas lahan yang mempraktekan sistem pertanian organik di Indonesia sampai tahun 2012 mencapai lebih dari 200.000 ha (Husnain, et al, 2015), dan masuk ke dalam kelompok negara dengan luas lahan pertanian organik tertinggi di Asia yaitu berada pada peringkat ke 4 setelah Tiongkok, India, dan Kazastan sedangkan pada tingkatan global pada tahun 2015 luas lahan pertanian organik mencapai 50,9 juta hektar (Willer \& Lernoud, 2017).

Provinsi Nusa Tenggara Barat (NTB), khususnya di Kota Mataram adalah daerah yang memiliki potensi lahan untuk pertanian organik yang cukup besar dan saat ini sudah menetapkan kebijakan penggunaan bahan-bahan organik kepada petani dalam melakukan usahataninya. Saat ini permintaan hasil pertanian organik di Kota Mataram oleh hotel maupun restoran terus mengalami peningkatan sehingga petani ada yang sudah mulai menggunakan pupuk maupun pestisida organik dalam usaha tani mereka.. Hal tersebut didukung juga dengan adanyakebijakanyang dilakukan untuk mendukung penerapan pertanian organik di Kota Mataram yaitu memberikan bantuan sarana produksi berupa alat pencacah pupuk organik kepada setiap kelompok tani. Namun pada kenyataanya, hingga saat ini masih sedikit petani yang mau melakukan sistem pertanian organik dalam usaha taninya. Hal ini dikarenakan petani masih menilai pertanian organik hampir memberikan keuntungan yang sama dengan pertanian konvensional sehingga petani masih memilih bertahan dengan pertanian konvensional(Argiles \& Brown 2010). Padahal jika mampu dikelola dengan baik pertanian organik dapat memberikan keuntungan yang lebih tinggi daripada pertanian konvensional seperti hasil temuan Hidayat \& Lesmana (2011) dan Sukristiyonubowo, et al. (2011). Faktor penyuluhan pertanian, peran media massa dan lingkungan sosial merupakan faktor-faktor yang penting dalam mempengaruhi petani melakukan praktik pertanian organik (Redono, 2016), modal, harga pasar (Ceylan et al., 2010) dan bantuan pemerintah berupa subsidi dan sarana produksi (Zhang, 2011). Berdasarkan uraian di atasTmaka penelitian ini berujuan untuk mengetahui respon petani terhadap sistem pertanian organik, dan mengidentifikasi faktor-faktor apa saja yang mendorong petani dalam menerapkan sistem pertanian organik di Kota Mataram.

\section{MATERI DAN METODE}

Penelitian ini dilaksanakan di Kecamatan Selaparang dan Kecamatan Sekarbela Kota Mataram yang dipilih secara purposive sampling atas pertimbangan bahwa kedua kecamatan tersebut merupakan daerah dengan jumlah petani terbanyak yang melakukan praktik pertanian organik maupun non organik Pendkatan metode deskriptif dipilih dalam menganalsis data.. Jenis data pada penelitian ini dalah data cross section yang diperoleh dari wawancara langsung terhadap 
responden penelitian sebanyak 40 orang yang diambil secara quota sampling .. Analisis data "kategorikal" digunakan untuk menganalisis data penelitian berupa respon petani terhadap usahatani organik. Respon petani terhadap pertanian organik digunakan 4 indikator yaitu pengetahuan, persepsi, sikap dan praktek atau penerapan.

Analisis kategorika dilakukan dengan cara menentukan skor maksimum dan skor minimum terlebih dahulu. Penentuan skor maksimum dan skor minimum dapat dihitung menggunakan rumus Skor maksimum $=\sum$ item $\times \sum$ skor tertinggi dan Skor minimum $=\sum$ item $\times \sum$ skor terendah, selanjutnya untuk mengetahui interval skor dihitung dengan rumus Interval Skor (IS) = skor maksimum- Skor Minimum / Jumlah Kategori

\section{HASIL DAN PEMBAHASAN}

\section{Respon Petani terhadap Pertanian Organik}

Respon petani terhadap pertanian organik digunakan 4 indikator yaitu pengetahuan, persepsi, sikap dan praktek atau penerapan.

\section{Pengetahuan Petani tentang Pertanian Organik}

Pengetahuan yang dimaksud pada penelitian ini adalah pengetahuan petani terhadap pertanian organik, pengetahuan diukur dengan kemampuan petani bisa menyebutkan dan menjelaskan definisi pertanian organik, manfaat pertanian organik, keuntungan ekonomi pertanian organik dan teknologi yang dimiliki oleh pertanian organik. Pengetahuan petani responden terhadap Pertanian Organik di Kota Mataram berada pada kategori sedang yaitu sebanyak 18 petani atau (45\%), 13 petani responden atau (32.5\%) berada pada kategori rendah dan 9 petani responden atau (22.5\%) berada pada kategori berpengetahuan tinggi tentang Pertanian Organik di Kota Mataram. Secara jelas dapat dilihat pada Tabel 1 di bawah ini.

Tabel 1. Sebaran responden menurut kategori pengetahuan petani organik dan non petani organik tentang pertanian organik Tahun 2019

\begin{tabular}{|c|c|c|c|c|c|c|}
\hline \multirow[t]{2}{*}{ No. } & \multirow{2}{*}{$\begin{array}{c}\text { Kategori } \\
\text { Pengetahuan }\end{array}$} & \multirow[t]{2}{*}{ Kisaran Skor } & \multicolumn{2}{|c|}{$\begin{array}{l}\text { Jumlah Responden } \\
\text { Petani Organik }\end{array}$} & \multicolumn{2}{|c|}{$\begin{array}{l}\text { Jumlah Responden } \\
\text { Non Petani Organik }\end{array}$} \\
\hline & & & $n$ & $\%$ & $\mathrm{n}$ & $\%$ \\
\hline 1. & Tinggi & $10-12$ & 9 & 45 & 0 & 0 \\
\hline 2. & Sedang & $7-9$ & 6 & 30 & 12 & 60 \\
\hline 3. & Rendah & $4-6$ & 5 & 25 & 8 & 40 \\
\hline \multicolumn{3}{|c|}{ Jumlah } & 20 & 100 & 20 & 100 \\
\hline
\end{tabular}

Sumber : Data Primer Diolah 2019

Tabel di atas dapat dilihat bahwa pengetahuan petani organik tentang pertanian organik berada pada kategori tinggi yaitu sebanyak 9 petani atau (45\%) karena dari pertanyaan yang diberikan mengenai, manfaat pertanian organik, teknologi pertanian organik dan manfaat ekonomi pertanian organik, responden mampu menjawab keseluruhan dari aspek pengetahuan tentang pertanian organik, pengetahuan responden mampu menjawab keseluruhan seperti yang diungkapkan oleh salah satu reponden mengenai pertanian organik. Responden mengatakan bahwa pertanian organik merupakan pertanian yang hanya menggunakan pupuk organik, pestisida organik, bibit atau benih organik dan cara pasca panen yang organik. Hal isi sesuai dengan pendapat (Mayrowani, 2016) bahwa pertanian organik adalah pertanian dengan teknik budidaya menggunakan bahan-bahan alami tanpa bahan-bahan kimia, Sedangkan 6 petani responden atau (30\%) berada pada katagori pengetahuan sedang hal ini dikarenakan petani responden hanya mampu menyebutkan akan tetapi tidak mampu menjelaskan pengertian pertanian organik, manfaat pertanian organik, teknologi yang dimiliki pertanian organik dan manfaat ekonomi dari pertanian organik dan 5 petani responden atau (25\%) berada pada kategori pengetahuan rendah hal tersebut dikarenakan petani responden tidak mampu untuk menyebutkan dan menjelaskan dengan baik dan benar mengenai pengertian pertanian organik, manfaat pertanian organik, teknologi yang dimiliki Pertanian organik dan manfaat ekonomi pertanian organik.

Pengetahuan petani non organik tentang pertanian organik berada pada kategori sedang yaitu sebanyak 12 petani atau $(60 \%)$ karena dari pertanyaan yang diberikan mengenai, manfaat pertanian organik, teknologi pertanian organik dan manfaat ekonomi pertanian organik, responden hanya bisa menjawab setengah atau sebagian dari aspek pengetahuan tentang pertanian organik standar, pengetahuan responden hanya mampu menjawab sebagian saja seperti yang diungkapkan oleh salah satu reponden mengenai pertanian organik. Responden mengatakan bahwa pertanian 
organik merupakan pertanian yang hanya menggunakan pupuk organik saja. Sehingga pengetahuan petani terhadap pertanian organik berada pada kategori sedang, sedangkan 6 petani responden atau $(40 \%)$ berada pada katagori pengetahuan rendah hal ini dikarenakan petani responden tidak bisa menyebutkan dan menjelaskan pengertian pertanian organik, manfaat pertanian organik, teknologi yang dimiliki pertanian organik dan manfaat ekonomi pertanian organik. Lebih jelasnya mengenai pengetahuan petani organik dan petani non organik terhadap pertanian organik dapat dilihat pada Tabel 2 berikut ini.

Tabel 2. Sebaran Responden petani organik dan petani non organik menurut Indikator Pengetahuan Terhadap Pertanian Organik 2019

\begin{tabular}{clcccccc}
\hline \multirow{2}{*}{ No } & Aspek pengetahuan & \multicolumn{2}{c}{ Skor 3 } & \multicolumn{2}{c}{ Skor 2 } & \multicolumn{2}{c}{ Skor 1 } \\
\cline { 3 - 8 } & $\mathrm{n}$ & $\%$ & $\mathrm{n}$ & $\%$ & $\mathrm{n}$ & $\%$ \\
\hline 1. & Definisi pertanian organik & 22 & 55 & 8 & 20 & 10 & 25 \\
2. & Manfaat pertanian Organik & 19 & 47.5 & 8 & 20 & 13 & 32.5 \\
3. & Keuntungan ekonomi Pertanian organik & 3 & 7.5 & 13 & 32.5 & 14 & 35 \\
4. & Teknologi yang dimiliki pertanian organik & 8 & 20 & 12 & 30 & 20 & 50 \\
\hline
\end{tabular}

Sumber : Data Primer Diolah 2019

Hasil penelitian menunjukkan bahwa 22 responden sudah mampu menjelaskan apa yang dimaksud dengan pertanian organik seperti yang diungkapkan oleh responden bahwa pertanian organik adalah pertanian yang dalam proses usaha taninya hanya menggunakan bahan-bahan yang organik atau alami. selanjutnya 19 responden mampu menyebutkan apa manfaat dari pertanian organik seperti dapat memperbaiki struktur tanah, dapat menyuburkan tanah, mengurangi terjadinya pencemaran lingkungan dan hasil komoditi pertanian yang sehat. Sedangkan 14 dari 40 responden tidak mampu menyebutkan apa manfaat dari pertanian organik.

\section{Persepsi Petani Terhadap Pertanian Organik}

Persepsi petani responden terhadap Pertanian Organik di Kota Mataram berada pada kategori kurang baik yaitu sebanyak 20 petani $(50 \%), 18$ petani responden (45\%) berada pada kategori tidak baik dan 2 petani responden atau (5\%) berada pada kategori baik terhadap Pertanian Organik di Kota Mataram. Secara jelas persepsi petani terhadap Pertanian Organik dapat dilihat pada Tabel 3 berikut ini :

Tabel 3. Sebaran responden menurut kategori persepsi petani organik dan non petani organik terhadap pertanian organik Tahun 2019

\begin{tabular}{|c|c|c|c|c|c|c|}
\hline \multirow[t]{2}{*}{ No. } & \multirow{2}{*}{ Kriteria Persepsi } & \multirow[t]{2}{*}{ Kisaran Skor } & \multicolumn{2}{|c|}{$\begin{array}{l}\text { Jumlah Responden } \\
\text { Petani Organik }\end{array}$} & \multicolumn{2}{|c|}{$\begin{array}{l}\text { Jumlah Responden } \\
\text { Non Petani Organik }\end{array}$} \\
\hline & & & $\mathrm{n}$ & $\%$ & $\mathrm{n}$ & $\%$ \\
\hline 1. & Tidak Baik & $6-10$ & 8 & 40 & 10 & 50 \\
\hline 2. & Kurang Baik & $11-14$ & 12 & 60 & 8 & 40 \\
\hline 3. & Baik & $15-18$ & 0 & 0 & 2 & 10 \\
\hline \multicolumn{3}{|c|}{ Jumlah } & 20 & 100 & 20 & 100 \\
\hline
\end{tabular}

Sumber : Data Primer Diolah 2019

Tabel 3 menjelaskan bahwa persepsi petani organik terhadap pertanian organik termasuk dalam kategori kurang baik yang ditunjukkan oleh 12 responden atau $(60 \%)$. Hal ini dikarenakan responden berpendapat bahwa pertanian organik kurang cocok dengan keadaan lingkungan dikota mataram, untuk mendapatkan saprodi cukup susah karena harus menunggu dari PPL, serta mereka berpendapat bahwa tingkat biaya yang dikeluarkan pada sistem pertanian organik sama dengan biaya pada sistem pertanian konvensional. Sedangkan 12 petani organik atau (60\%) berada pada kategori persepsi tidak baik, Hal ini dikarenakan mereka menganggap bahwa pertanian organik tidak menguntungkan karena membutuhkan tenaga kerja yang lebih banyak, tingkat kemudahan untuk mendapatkan pupuk serta pestisida organik sangat susah, harga komoditi lebih murah dan biaya yang dikeluarkan pada pertanian organik lebih tinggi dari pertanian konvensional. Argiles \& Brown (2010) juga menemukan bahwa pertanian organik hampir sama dengan pertanian konvensional dalam hal biaya produksi dan keuntungan yang diperoleh petani, perbedaannya adalah biaya tenaga kerja pada pertanian organi lebih tinggi, sedangkan biaya saprotan (pupuk dan pestisida) lebih rendah dibandingkan dengan pertanian konvensional. 
Sedangkan persepsi petani non organik terhadap pertanian organik termasuk dalam kategori tidak baik yang ditunjukkan oleh 10 responden atau (50\%). Hal ini dikarenakan responden berpendapat bahwa pertanian organik tidak cocok dengan keadaan lingkungan dikota mataram, untuk mendapatkan saprodi sangat susah karena harus menunggu dari PPL, serta mereka berpendapat bahwa tingkat biaya sistem pertanian organik lebih tinggi dibandingkan dengan biaya pertanian konvensional, pertanian organik tidak menguntungkan karena membutuhkan tenaga kerja yang lebih banyak, tingkat kemudahan untuk mendapatkan pupuk serta pestisida organik sangat susah, dan 8 petani atau (40\%) berada pada kategori persepsi kurang baik, Hal ini dikarenakan mereka menganggap bahwa pertanian organik kurang menguntungkan karena membutuhkan tenaga kerja yang lebih banyak, tingkat kemudahan untuk mendapatkan pupuk serta pestisida organik lumayan susah, harga komoditi dianggap sama dan biaya yang dikeluarkan pada pertanian organik sama dengan pertanian konvensional. Pendapat ini sesuai dengan temuan Seufert et al., (2012) bahwa keuntungan pertanian organic lebih rendah dibandingkan pertanian konvensional pada jenis buah-buahan Sementara itu 2 petani responden atau (10\%) berada pada kategori persepsi baik, karena responden beranggapan bahwa pertanian organik lebih menguntungkan serta bahan-bahan yang digunakan sebagai pupuk dan pestisida sudah tersedia, pertanian organik sangat cocok atau sesuai lingkungan karena dapat menyuburkan tanah serta memperbaiki struktur tanah, untuk mendapatkan saprodi pupuk maupun pestisida sangat mudah karena bisa diproduksi sendiri maupun membeli di toko yang tersedia. Hasil yang diperoleh dengan menerapkan pertanian organik dari kualitas hasil lebih baik, yaitu beras yang dihasilkan lebih putih, butiran beras tidak pecah, nasi lebih tahan lama dan dari segi rasa lebih enak serta harga komoditi yang lebih tinggi. Untuk lebih jelasnya mengenai persepsi petani organik dan petani non organik terhadap pertanian organik dapat dilihat pada Tabel 4 di bawah ini:

Tabel 4. Sebaran responden menurut indikator persepsi petani organik dan petani non organik terhadap pertanian organik Tahun 2019

\begin{tabular}{|c|c|c|c|c|c|c|c|}
\hline \multirow{2}{*}{ No } & \multirow{2}{*}{ Aspek Persepsi } & \multicolumn{2}{|c|}{ Skor 3} & \multicolumn{2}{|c|}{ Skor 2} & \multicolumn{2}{|c|}{ Skor 1} \\
\hline & & $\mathrm{n}$ & $\%$ & $\mathrm{n}$ & $\%$ & $\mathrm{n}$ & $\%$ \\
\hline 1. & Mengapa Pertanian organik perlu di terapkan & 11 & 27.5 & 16 & 40 & 13 & 32.5 \\
\hline 2. & $\begin{array}{l}\text { Apakah pertanian organik cocok untuk } \\
\text { lingkungan }\end{array}$ & 3 & 7.5 & 4 & 10 & 33 & 82.5 \\
\hline 3. & $\begin{array}{l}\text { Tingkat kemudahan Mendapatkan Saprodi } \\
\text { (Pupuk). }\end{array}$ & 8 & 20 & 19 & 47.5 & 13 & 0 \\
\hline 4. & Tingkat Kemudahan Mendapatkan Pestisida & 7 & 17.5 & 19 & 47.5 & 14 & 0 \\
\hline 5. & $\begin{array}{l}\text { Hasil yang diperoleh dengan penerapan } \\
\text { pertanian organic }\end{array}$ & 1 & 2.5 & 19 & 47.5 & 20 & 50 \\
\hline 6. & $\begin{array}{l}\text { Biaya Produksi dalam penerapan pertanian } \\
\text { organik }\end{array}$ & 16 & 40 & 12 & 30 & 12 & 30 \\
\hline
\end{tabular}

Sumber : Data Primer Diolah 2019

Tabel 4 di atas dapat diketahui bahwa 16 responden atau (40\%) menyebutkan bahwa alasan mengapa pertanian organik itu penting dikarenakan bahwa lebih menguntungkan baik secara ekonomi maupun bagi lingkungan seperti dapat membatasi terjadinya pencemaran lingkungan, serta mereka berpendapat bahwa pertanian konventional menggunakan bahan kimia yang berbahaya. Beberapa penelitian sebelumnya juga menemukan bahwa pertanian organik lebih tinggi daripada keuntungan dari pertanian konvensional (Hidayat \& Lesmana, 2011; dan Sukristiyonubowo, et al. 2011), sedangkan pada tingkat hasil yang diperoleh dengan penerapan pertanian organik, 20 petani responden atau (50\%) petani mengatakan bahwa hasil yang diperoleh sedikit dikarenakan tingkat gulma yang semakin meningkat sehingga unsur hara yang ada diserap oleh gulma tersebut. Penelitian (Seufert, et al, 2012) juga menemukan bahwa hasil pertanian organik $25 \%$ lebih rendah daripada pertanian konvensional untuk jenis buah-buahan.

\section{Sikap Petani terhadap Pertanian Organik}

Sikap merupakan ungkapan perasaan seseorang terhadap suatu objek, atau rasa senang, tidak senang, rasa suka atau tidak suka terhadap pertanian organik. Secara keseluruhan bahwa kriteria sikap petani responden terhadap Pertanian organik termasuk dalam ketegori setuju yaitu sebanyak 33 petani responden atau (82.5\%) dan 7 petani responden atau (17.5\%) berada pada kategori kurang setuju. Untuk lebih jelasnya sikap masyarakat terhadappertanian organik dapat dilihat pada Tabel 5 berikut ini : 
Tabel 5. Sebaran responden menurut kategori sikap petani organik dan non petani organik terhadap pertanian organik Tahun 2019

\begin{tabular}{llccccc}
\hline \multirow{2}{*}{ No. } & \multirow{2}{*}{ Kategori Sikap } & Kisaran Skor & \multicolumn{2}{c}{$\begin{array}{c}\text { Jumlah Responden } \\
\text { Petani Organik }\end{array}$} & \multicolumn{2}{c}{$\begin{array}{c}\text { Jumlah Responden } \\
\text { Non Petani Organik }\end{array}$} \\
\cline { 3 - 6 } & & $\mathrm{n}$ & $\%$ & $\mathrm{~N}$ & $\%$ \\
\hline 1. & Tidak Setuju & $6-10$ & 0 & 0 & 0 & 0 \\
2. & Kurang Setuju & $11-14$ & 1 & 5 & 6 & 30 \\
3. & Setuju & $15-18$ & 19 & 95 & 14 & 70 \\
\hline & Jumlah & & 20 & 100 & 20 & 100 \\
\hline
\end{tabular}

Sumber : Data Primer Diolah 2019

Berdasarkan Tabel $5 \mathrm{di}$ atas, hasil penelitian menunjukkan bahwa sikap petani organik terhadap pertanian organik berada dalam kategori setuju sebesar $95 \%$, petani berpendapat bahwa pertanian organik tidak terlalu rumit, biaya serta proses produksi pada pertanian organik lebih rendah dibandingkan dengan pertanian konventional kemudian untuk mendapatkan saprodi pada pertanian organik lebih mudah karena petani bisa memproduksi sendiri pupuk dan pestisida organik serta mereka beranggapan bahwa dengan menerapkan pertanian organik maka tanah lebih sehat dan gembur, aman untuk lingkungan, lebih menguntungkan dari segi ekonomi.

Sedangkan sikap petani non organik terhadap pertanian organik berada dalam kategori setuju yaitu sebesar 14 petani responden atau (70\%) berada pada kategori sikap setuju terhadap penerapan pertanian organik. Hal tersebut dikarenakan mereka beranggapan bahwa dengan menerapkan pertanian organik maka tanah lebih sehat dan gembur, aman untuk lingkungan, lebih menguntungkan dari segi ekonomi. Pendapat ini sesuai dengan temuan (FAO, 2011; Gattinger, et al. 2012) bahwa pertanian organik menjadikan tanah lebih subur dan aman bagi lingkungan. Selain itu berdasarkan temuan menguntungkan dari segi ekonomis berdasarkan temuan Hidayat \& Lesmana (2011) dan Sukristiyonubowo, et al. (2011). Untuk lebih jelasnya mengenai sikap petani organik dan petani non organik terhadap pertanian organik dapat dilihat pada Tabel 6 di bawah ini:

Tabel 6. Sebaran Responden Menurut Indikator Sikap Petani Terhadap Pertanian Organik Tahun 2019

\begin{tabular}{|c|c|c|c|c|c|c|c|}
\hline \multirow{2}{*}{ No } & \multirow{2}{*}{ Aspek Sikap } & \multicolumn{2}{|c|}{ Skor 3} & \multicolumn{2}{|c|}{ Skor 2} & \multicolumn{2}{|c|}{ Skor 1} \\
\hline & & $\mathrm{n}$ & $\%$ & $\mathrm{n}$ & $\%$ & $\mathrm{n}$ & $\%$ \\
\hline 1. & $\begin{array}{l}\text { Apakah Petani Setuju dalam } \text { Menerapkan } \\
\text { pertanian organik }\end{array}$ & 37 & 92.5 & 3 & 7.5 & 0 & 0 \\
\hline 2. & $\begin{array}{l}\text { Bila petani menganggap pertanian organik aman } \\
\text { untuk lingkungan, apakah petani tertarik untuk } \\
\text { menerapkanya }\end{array}$ & 39 & 97.5 & 1 & 2.5 & 0 & 0 \\
\hline 3. & $\begin{array}{l}\text { Dari manfaat ekonomi yang diketahui, apakah } \\
\text { petani tertarik untuk menerapkanya }\end{array}$ & 39 & 97.5 & 1 & 2.5 & 0 & 0 \\
\hline 4. & $\begin{array}{l}\text { Apakah petani setuju bahwa untuk mendapatkan } \\
\text { saprodi sangat mudah }\end{array}$ & 26 & 65 & 7 & 17.5 & 7 & 17.5 \\
\hline 5. & $\begin{array}{l}\text { Dari teknologi yang diketahui, apakah petani } \\
\text { tertarik untuk menerapkanya } \\
\text { Jika petani menqanqaan bahwa biava dan proses }\end{array}$ & 35 & 87.5 & 5 & 12.5 & 0 & 0 \\
\hline 6. & $\begin{array}{l}\text { produksi lebih murah dan mudah pada pertanian } \\
\text { organik, apakah petani tertarik untuk } \\
\text { menerapkanya }\end{array}$ & 33 & 82.5 & 5 & 12.5 & 2 & 5 \\
\hline
\end{tabular}

Sumber : Data Primer Diolah 2019

Tabel 6 menunjukkan bahwa 37 responden atau (92.5\%) setuju dalam menerapkan pertanian organik, alasannya karena pertanian organik aman untuk lingkungan, dapat memperbaiki struktur tanah. Sedangkan 39 reponden atau (97.5\%) menjawab bahwa pertanian organik dapat membuat tanah semakin gembur.. Dimana menurut FAO, (2011); dan Gattinger, et al. (2012) bahwa pertanian organik menjadikan tanah lebih subur dan aman bagi lingkungan 


\section{Praktik atau Menerapkan Pertanian Organik}

Praktek petani responden terhadap Pertanian Organik berada pada kategori sedang yaitu sebanyak 22 petani atau (55\%), 16 petani responden atau (40\%) berada pada kategori rendah dan 2 petani responden atau (5\%) berada pada kategori tinggi.Untuk lebih jelas dapat dilihat pada Tabel 7 berikut ini:

Tabel 7. Sebaran responden menurut adopsi pertanian organik oleh petani organik Tahun 2019

\begin{tabular}{|c|c|c|c|c|c|c|}
\hline \multirow[t]{2}{*}{ No } & \multirow{2}{*}{$\begin{array}{c}\text { Kriteria Praktek } \\
\text { atau Menerapkan }\end{array}$} & \multirow[t]{2}{*}{ Kisaran Skor } & \multicolumn{2}{|c|}{$\begin{array}{l}\text { Jumlah Responden } \\
\text { Petani Organik }\end{array}$} & \multicolumn{2}{|c|}{$\begin{array}{l}\text { Jumlah Responden } \\
\text { Non Petani Organik }\end{array}$} \\
\hline & & & $\mathrm{n}$ & $\%$ & $\mathrm{n}$ & $\%$ \\
\hline 1. & Tinggi & $10-12$ & 2 & 10 & 0 & 0 \\
\hline 2. & Sedang & 7-9 & 18 & 90 & 5 & 25 \\
\hline 3. & Rendah & $4-6$ & 0 & 0 & 15 & 75 \\
\hline \multicolumn{3}{|c|}{ Jumlah } & 20 & 100 & 20 & 100 \\
\hline
\end{tabular}

Sumber : Data Primer Diolah 2019

Tabel 7 di atas dapat diketahui bahwa pada tahap praktek atau penerapan pertanian organik oleh petani organik berada pada kategori sedang yaitu sebanyak 18 petani atau $90 \%$ hal tersebut dikarenakan petani tidak sepenuhnya menerapkan Pertanian Organik, akan tetapi petani hanya menggunakan cara bercocok tanam secara semi organik seperti sebelum tanam harus memberikan pupuk organik pada tanah yang akan ditanami, penggunaan pestisida organik dengan campuran pestisida kimia dan dengan penggunaan pupuk organik diseling dengan penggunaan pupuk berbahan kimia. Petani menggunakan pestisida yang diseling alasanya bahwa petani masih kurang yakin dengan pestisida nabati, mereka menganggap bahwa dengan penggunaan pestisida organik sepenuhnya hasilnya akan lama kelihatan seperti penggunaan pestisida daun nimba, sedangkan penggunaan bibit atau benih yang organik ini lumayan sulit Hal ini dikarenakan petani beranggapan bahwa tidak ada toko yang menjual saprodi berupa bibit atau benih yang $100 \%$ organik sehingga mereka masih menerapkan bibit/benih yang ada di toko serta kadang-kadang mendapat bantuan berupa bibit dari pemerintah. dan 2 petani responden atau 10\% berada pada kategori tinggi hal tersebut dikarenakan petani menerapkan hampir sebagian besar cara bercocok tanam secara organik, seperti sebelum tanam harus memberikan pupuk organik pada tanah yang akan ditanami, penggunaan pestisida organik untuk membasmi hama dan penyakit seperti daun nimba, gadung racun, serai, lengkuas, sirsak dan srikaya serta penggunaan pupuk organik untuk menunjang pertumbuhan tanaman.

Praktek atau penerapan pertanian organik oleh non petani organik berada pada kategori rendah yaitu sebanyak 15 petani atau $75 \%$ petani responden berada pada kategori rendah. Hal tersebut dikarenakan petani tidak menerapkan pertanian organik sama sekali, petani tidak menggunakan pestisida organik pada pertanian mereka, pada saat pengolahan lahan tidak memberikan pupuk organik, penggunaan pupuk kimia pada saat melakukan pemupukan serta penggunaan bibit/benih kimia pada pertanian mereka.Sedangkan 5 petani responden berada pada kategori sedang. Hal tersebut dikarenakan petani tidak sepenuhnya menerapkan cara bercocok tanam secara organik, akan tetapi petani hanya menggunakan cara bercocok tanam secara semi organik seperti sebelum tanam harus memberikan pupuk organik pada tanah yang akan ditanami, penggunaan pestisida organik dengan campuran pestisida kimia dan dengan penggunaan pupuk organik diseling dengan penggunaan pupuk berbahan kimia. Untuk lebih jelasnya dapat dilihat pada Tabel 8 di bawah ini:

Tabel 8. Sebaran responden menurut indikatoradopsi pertanian organik oleh petani organik dan petani non organik Tahun 2019

\begin{tabular}{|c|c|c|c|c|c|c|c|c|}
\hline \multirow{2}{*}{ No } & \multirow{2}{*}{\multicolumn{2}{|c|}{ Aspek Praktek }} & \multicolumn{2}{|c|}{ Skor 3} & \multicolumn{2}{|c|}{ Skor 2} & \multicolumn{2}{|c|}{ Skor 1} \\
\hline & & & $\mathrm{n}$ & $\%$ & $\mathrm{n}$ & $\%$ & $\mathrm{n}$ & $\%$ \\
\hline 1. & $\begin{array}{l}\text { Penerapan Cara pengolahan Lahan } \\
\text { organik }\end{array}$ & secara & 3 & 7.5 & 7 & 17.5 & 30 & 75 \\
\hline 2. & Penggunaan Pestisida organik & & 3 & 7.5 & 16 & 40 & 21 & 52.5 \\
\hline 3. & Penggunaan bibit atau benih organik & & 0 & 0 & 13 & 32.5 & 27 & 67.5 \\
\hline 4. & Penggunaan pupuk organik & & 21 & 52.5 & 16 & 40 & 3 & 7.5 \\
\hline
\end{tabular}


Tabel di atas dapat diketahui bahwa 30 reponden atau (75\%) masih menerapkan Penerapan cara pengolahan lahan secara organik sangat rendah, hal tersebut dikarenakan penggunaan pupuk atau bahan organik sebelum tanam sangat banyak sehingga petani tidak sepenuhnya menerapkan, selanjutnya pada penggunaan pestisida hayati, 21 reponden atau $(52,5)$ masih rendah dalam penerapanya hal tersebut dikarenakan petani masih susah untuk mendapatkan pestisida hayati di toko, walaupun petani bisa memproduksi sendiri akan tetapi petani malas untuk memproduksinya hal tersebut dikarenakan petani lebih suka menggunakan yang instan atau siap untuk diaplikasikan.

\section{Respon petani Terhadap Pertanian Organik}

Respon petani terhadap pertanian organik di Kota Mataram digunakan 4 indikator yang telah dikemukakan di atas yaitu pengetahuan, persepsi, sikap dan praktek atau penerapan. Secara jelas respon Petani Terhadap Pertanian Organik dapat dilihat pada Tabel 9 di bawah ini:

Tabel 9. Sebaran responden menurut kategori respon petani organik dan non petani organik terhadap pertanian organik Tahun 2019

\begin{tabular}{llccccc}
\hline \multirow{2}{*}{ No. } & \multirow{2}{*}{ Kategori Respon } & Kisaran Skor & \multicolumn{2}{c}{$\begin{array}{c}\text { Jumlah Responden } \\
\text { Petani Organik }\end{array}$} & \multicolumn{2}{c}{$\begin{array}{c}\text { Jumlah Responden } \\
\text { Non Petani Organik }\end{array}$} \\
\cline { 3 - 6 } & & $\mathrm{n}$ & $\%$ & $\mathrm{n}$ & $\%$ \\
\hline 1. & Positif & $48-60$ & 13 & 65 & 0 & 0 \\
2. Kurang positif/Sedang & $34-47$ & 7 & 35 & 19 & 95 \\
3. & Negatif & $20-33$ & 0 & 0 & 1 & 1 \\
& & 20 & 100 & 20 & 100 \\
\hline
\end{tabular}

Sumber : Data Primer Diolah 2019

Hasil penelitian dapat dilihat bahwa respon petani organik terhadap pertanian organik di Kota Mataram berada pada kategori positif, dimanahal ini ditunjukkan oleh 13 petani atau (65\%) petani berada pada kisaran positif. Respon petani organik terhadap pertanian organik di Kota Mataram positif dikarenakan oleh manfaat dari penerapan pertanian organik terhadap tingkat kesuburan tanah sangat tinggi, mengurangi pencemaran lingkungan dengan penerapan pertanian organik serta dapat menjaga pertanian yang berkelanjutan, pertanian organik dapat memperbaiki struktur tanah yang telah rusak, memiliki ikatan yang kuat dengan unsur-unsur yang terdapat didalam tanah, bahan-bahan yang digunakan menjadi saprodi atau pupuk dan pestisida sudah tersedia melimpah disekitar tempat tinggal, produk yang dihasilkan sehat karena tidak terdapat unsur kimiawi serta yang paling penting adalah tetap menjaga pertanian berkelanjutan untuk anak cucu pada masa yang akan datang. Pendapat ini sesuai dengan temuan FAO, (2011; dan Gattinger, et al. (2012)bahwa sistem pertanian organik mampu meningkatkan dan mengembangkan kelestarian lingkungan, keragaman hayati, siklus dan aktivitas biologi tanah, serta bersifat adaptif .Sedangkan 7 petani responden atau (35\%) memberikan respon yang sedang atau kurang positif. Hal tersebut dikarenakan responden berpendapat bahwa respon petani terhadap pertanian organik di Kota Mataram kurang positif/sedang dikarenakan oleh masih rumitnya penerapan pertanian organik baik dari segi pemupukan maupun pada saat melakukan peyemprotan hama dan penyakit, Hal ini dikarenakan pada saat melakukan penyemprotan dengan menggunakan daun nimba sebagai pestisida, petani harus melakukan pengeringan terlebih dahulu selanjutnya akan melakukan penggilasan daun tersebut baru bisa diaplikasikan dilahan, selanjutnya tingginya tingkat biaya yang dikeluarkan, hasil yang lama kelihatan serta pengalaman pada tahun lalu yang masih kurang menguntungkan petani

Respon petani non organik terhadap pertanian organik di Kota Mataram berada pada kategorisedang/kurang positif, dimanahal ini ditunjukkan oleh 19 petani atau $(97 \%)$ responden petani non organik berada pada kisaran skor kurang positif/sedang. Respon petani non organik terhadap pertanian organik di Kota Mataram kurang positif/sedang dikarenakan masih rumitnya dalam penerapan pertanian organik. Pertanian organik masih rumit dari segi pemupukan maupun pada saat melakukan peyemprotan hama dan penyakit. Hal ini dikarenakan pada saat melakukan penyemprotan dengan menggunakan daun srikaya atau sirsak sebagai pestisida, petani responden harus melakukan pengeringan terlebih dahulu selanjutnya akan melakukan penggilasan daun tersebut baru bisa di gunakan dilahan mereka, selanjutnya tingkat biaya yang dikeluarkan antara pertanian organik dan conventional masih dianggap sama. Sedangkan 1 responden petani organik atau $(5 \%)$ memiliki respon yang negatife terhadap pertanian organik karena petani menganggap bahwa pertanian organik membutuhkan biaya yang tinggi apabila dibandingkan dengan pertanian konvensional serta pengaplikasianya lebih rumit dan kuantitas hasil yang didapatkan tidak sebaik penerapan pertanian konvensional. 


\section{Faktor-faktor yang Pendukung Petani dalam Menerapakan Pertanian Organik}

Faktor-faktor yang mendukung petani organik dan non organik dalam menerapkan pertanian organik seperti pada Tabel 10 sebagai berikut.

Tabel 10. Faktor yang mendorong petani organik dan petani non organik dalam penerapan pertanian organik Tahun 2019.

\begin{tabular}{clcc}
\hline \multirow{2}{*}{ No } & \multicolumn{1}{c}{ Faktor Pendorong } & \multicolumn{2}{c}{ Jumlah Responden } \\
\cline { 3 - 4 } & Peran penyuluh & $\mathrm{n}$ & $\%$ \\
2 & Ketersediaan teknologi pertanian Organik & 30 & 37,5 \\
3 & Modal & 10 & 75 \\
\hline
\end{tabular}

Sumber : Data primer Diolah 2019

Tabel dapat diketahui bahwa faktor-faktor yang mendukung petani dalam penerapan Pertanian Organik adalah;Ketersediaan teknologi pertanian organik seperti adanya bantuan berupa mesin pencacah daun yang bisa digunakan petani dalam pembuatan pupuk organik, kemudian adanya bantuan pemerintah berupa pupuk organik dan pestisida hayati untuk di aplikasikan atau digunakan pada lahan petani yang ada di Kota Mataram sehingga petani tidak kesulitan dalam mendapatkan saprodi. Menurut Zhang (2011), untuk mempertahankan produksi pertanian organik yang berkelanjutan sangat diperlukan dukungan kebijakan pemerintah berupa subsidi dan bantuan sarana produksi. Peran penyuluh sangat penting dalam membimbing petani untuk mendapatkan pengetahuan dan keterampilan dalam menerapkan pertanian organik sebagian besar responden telah diberikan arahan serta bantuan berupa pupuk maupun pestisida organik yang diaplikasikan pada lahan mereka serta bimbingan cara pengaplikasianya yang benar. Kemudian Modal merupakan salah satu faktor yang mendorong petani mau melakukan pertanian organik, responden beranggapan bahwa modal merupakan salah satu faktor mengapa mereka mau menerapkan pertanian organik. Mereka mengatakan bahwa modal penerapan pertanian organik lebih sedikit daripada penerapan pertanian nonorganik. Penelitian Ceylan et al., (2010) dan Läpple \& van Rensburg (2011) menemukan bahwa faktor akses informasi atau peyuluhan dan modal berperan penting dalam mempengaruhi keputusan petani melakukan praktik pertanian organik.

\section{Faktor Penghambat Petani dalam Menerapkan Pertanian Organik}

Faktor- faktor penghambat petani organik dan petani non organik dalam penerapan pertanian organik dapat di lihat pada Tabel 11 berikut :

Tabel 11. Faktor penghambat petani dalam penerapan pertanian organik

\begin{tabular}{clcc}
\hline \multirow{2}{*}{ No Faktor Penghambat } & \multicolumn{2}{c}{ Jumlah responden } \\
\cline { 3 - 4 } & Pengalaman & $n$ & $\%$ \\
2 & Harga Pasar & 30 & 75 \\
3 & Akses informasi & 34 & 85 \\
4 & Modal & 34 & 85 \\
5 & Ketersediaan sarana produksi pertanian organik & 30 & 75 \\
\hline
\end{tabular}

Sumber : Data primer Diolah 2019

Tabel di atas menunjukkan bahwa faktor-faktor penghambat dalam penerapan pertanian organik di Kota Mataram adalah pengalaman, pasar, akses informasi, modal, ketersediaan teknologi pertanian. Dilihat dari pengalaman sebesar $75 \%$ reponden beranggapan bahwa mereka tidak setuju dalam menerapkan pertanian organik. Hal tersebut dikarenakan pada tahun sebelumnya mereka pernah menerapkan pertanian organik dan hasil yang didapatkan tidak sesuai dengan harapan. Menurut Xie et al., (2016), faktor tenaga kerja seperti umur dan pengalaman berpengaruh terhadap keputusan petani menerapkan pertanian organic.Harga Pasar Dari hasil penelitian bahwa pasar merupakan faktor yang sangat penting sehingga 34 responden atau (85\%) mengatakan bahwa harga pasar untuk produk pertanian lebih mahal, produk yang organik dengan non organik masih memiliki harga yang sama.

a. Akses informasi, dari hasil penelitian menunjukkan bahwa $85 \%$ petani responden berpendapat bahwa akses informasi merupakan faktor penghambat dalam penerapan pertanian organik hal tersebut dikarenakan mereka tidak tahu informasi tentang pertanian organik sehingga mereka kesulitan dalam penerapanya. 
b. Modal merupakan hal terpenting apabila melakukan proses usaha tani. Dari hasil penelitian bahwa $75 \%$ petani reponden menjadikan modal sebagai alasan mengapa mereka tidak mau menerapkan pertanian organik hal tersebut dikarenakan petani responden berpendapat bahwa modal yang dibutuhkan pada penerapan pertanian organic jauh lebih besar dibandingkan dengan penerapan pertanian nonorganik

c. Ketersediaan sarana produksi pertanian organik, dari hasil penelitian menunjukkan bahwa ketersediaan teknologi pertanian merupakan penghambat dalam penerapan pertanian organik. sebesar $25 \%$ petani responden mengatakan bahwa sulitnya teknologi pertanian organik seperti ketersediaan pestisida organik, tersedianya bibit/benih organik menjadi penghambat untuk menerapkan pertanian organik. . Penelitian Ceylan et al., (2010) menemukan bahwa faktor modal, akses informasi modal, harga pasar dan bantuan pemerintah berupa mesin berperan penting dalam mempengaruhi keputusan petani melakukan praktik pertanian organik.

\section{KESIMPULAN DAN SARAN}

Berdasarkan hasil dan pembahasan maka dapat disimpulkan bahwa respon petani organik terhadap pertanian organik di Kota Mataram berada pada kisaran positif. Respon petani organik terhadap pertanian organik di Kota Mataram positif dikarenakan responden beranggapan bahwa manfaat dari penerapan pertanian organik terhadap tingkat kesuburan tanah sangat tinggi, dapat mengurangi pencemaran lingkungan serta dapat menjaga pertanian yang berkelanjutan. Sedangkan respon petani non organik terhadap pertanian organik berada pada kisaran sedang/kurang positif. Hal tersebut dikarenakan masih rumitnya dalam penerapan pertanian organik baik dari segi pemupukan maupun pada saat melakukan peyemprotan hama dan penyakit. Faktor-faktor yang mendukung petani dalam menerapkan sistem pertanian organik di Kota Mataram adalah peran penyuluh, ketersediaan teknologi pertanian dan modal sangat berperan dalam penerapan pertanian organik. Sedangkan faktor-faktor yang menjadi penghambat petani menerapkan pertanian organik adalah pengalaman petani, harga produk organik yang sama dengan produk non organik, modal, akses informasi dan ketersediaan sarana produksi pertanian organik.

Berdasarkan kesimpulan, maka saran yang direkomendasikan yaitu pemerintah perlu meningkatkan akses informasi yang sudah ada, pemberian bantuan saprodi dan menyediakan teknologi pertanian organik guna menarik minat petani dalam melakukan praktikpertanian organik.Peran penyuluh harus lebih dioptimalkan dalam melakukan penyuluhan masalah pertanian organik, memberikan pelatihan maupun demplot dan dapat memberikan informasi dan akses pemasaran kepada petani lebih tertarik dalam penerapan pertanian organik.

\section{REFERENSI}

Argiles, J. M., \& Brown, N., D. (2010). A Comparative of the Economic and Environmental Performances of Conventional and Organic Farming: evidence from financial statements. Agricultural Economics Review, 11(1), 69-86.

Beddington J, Asaduzzaman M, Clark M, Fernández A, Guillou M, Jahn M, Erda L, Mamo T, Van Bo N, Nobre CA, Scholes R, Sharma R, W. J. (2012). Achieving food security in the face of climate change: Final report from the Commission on Sustainable Agriculture and Climate Change. The CGIAR Research Program on Climate Change, Agriculture and Food Security (CCAFS).

Ceylan, I. C., Olhan, E., \& Köksal, Ö. (2010). Determination of the effective factors on organic olive cultivation decision. Afr. J. Agric. Res, 5(23), 3164-3168.

FAO. (2011). Agriculture and Climate Change Organic. A Report of The Round Table on Organic Agriculture and Climate Change Organic. Food and Agriculture Organization of the United Nations.

FAO. (2013). Climate-Smart Agriculture. Fod and Agricultur Organiszaton of the United Nation.

Gattinger, A., Muller, A., Haeni, M., Skinner, C., Fliessbach, A., \& Buchmann, N. (2012). Enhanced top soil carbon stocks under organic farming. PNAS, 109(44), 18226-18231. https://doi.org/10.1073/pnas.1209429109

Hidayat, A. S., \& Lesmana, T. (2011). The development of rice organic farming in Indonesia. RIEBS, 2(1), 1-14.

Husnain, Nursyams, D., \& Purnomo, J. (2015). Pengelolaan Lahan pada Berbagai Ekosistem Mendukung Pertanian Ramah Lingkungan. AARD-PRESS.

Jahroh, S. (2010). Organic farming development in Indonesia: lessons learned from organic farming in West Java and North Sumatra. International Swaps and Derivatives Association (ISDA), 
$00521832 f$.

Kementerian Pertanian. (2016). Pengembangan Desa Pertanian Organik Padi Tahun 2016. Kementerian Pertanian Republik Indonesia.

Läpple, D., \& van Rensburg, T. (2011). Adoption of organic farming: Are there differences between early and late adoption? Ecol. Econ, 70(7), 406-1414.

Mayrowani, H. (2016). Pengembangan Pertanian Organik di Indonesia. Forum Penelitian Agro Ekonomi, 30(2), 91. https://doi.org/10.21082/fae.v30n2.2012.91-108

Redono, C. (2016). Respon petani terhadap penggunaan pupuk organik pada tanaman padi sawah di kelurahan bokoharjo kecamatan prambanan kabupaten sleman. Jurnal Agrica Ekstensia, 10(1), 29-36.

Setyanto, P. A., Wihardjaka, \& Kartikawati, R. (2013). Politik Pembangunan Pertanian menghadapi Perubahan Iklim. IAARD-PRESS.

Seufert, V., Ramankutty, N., \& Foley, J. A. (2012). Comparing the yields of organic and conventional agriculture. Nature, 485(7397), 229-232. https://doi.org/10.1038/nature11069

Shiotsu, F., Sakagami, N., Asagi, N., Suprapta, D. N., Agustiani, N., Nitta, Y., \& Komatsuzaki, M. (2015). Initiation and Dissemination of Organic Rice Cultivation in Bali, Indonesia. Sustainability, 7(7), 5171-5181. https://doi.org/10.3390/su7055171

Sudalmi, E. R. (2010). Pembangunan pertanian berkelanjutan endang sri sudalmi. Inovasi Pertanian, 9(2), 15-27. http://www.ejurnal.unisri.ac.id/index.php/innofarm/article/viewFile/28/2

Sukristiyonubowo R, H, W., A, S., H.P, B., \& Neve, S. De. (2011). Change from conventional to organic rice farming system: biophysical and socioeconomic reasons. International Research Journal of Agricultural Science and Soil Science, 1(5), 172-182.

Wibowo. (2012). Manajemen Kinerja (3rd ed.). Rajawali Pers.

Willer, H., \& Lernoud, J. (2017). The World of Organic Agriculture 2008: Summary. In The World of Organic Agriculture: Statistics and Emerging Trends 2008. Research Institute of Organic Agriculture (FiBL), Frick, and IFOAM - Organics International, Bonn. https://doi.org/10.4324/9781849775991

Xie, Y., Zhao, H., Pawlak, K., \& Gao, Y. (2016). the Development of Organic Agriculture in China and the Factors Affecting Organic Farming. Journal of Agribusiness and Rural Development, 9(2), 353-361. https://doi.org/10.17306/jard.2015.38

Zhang, X. (2011). Environmental benefi ts of organic agriculture - Farmers cognitive perspective based on empirical analysis. J. Soft Science, 25(7), 92-101. 